\title{
Cell immobilization by Gel Entrapment in Ca-alginate Beads for Balsamic-styled Vinegar Production
}

\author{
U.F. Hutchinson, S.K.O. Ntwampe, M. Mewa Ngongang, H.W. Du Plessis, B.S. Chidi, C.K.L.N. Saulse \\ and N.P. Jolly
}

\begin{abstract}
The production of a high concentration of acetic acid during vinegar fermentation is a desirable occurrence for Balsamic vinegar. However, acetic acid, high osmotic pressure and low water activity resulting from the cooked grape must, can negatively affect microbial growth during fermentation. To counteract these effects, cell immobilization can improve microbial activity by protecting the cells against harsh environmental conditions. The immobilization of the microbial consortia (non-Saccharomyces yeast and acetic acid bacteria) was carried out using the calcium alginate gel beads entrapment technique. A comparative analysis of the freely suspended and gel entrapped cells was done to further evaluate the effects of surface area or bead size on acetification rates under agitated and non-agitated fermentations. Gel entrapped cell fermentations showed higher acetification rates compared to freely suspended cell fermentations. Static fermentations achieved the anticipated acetic acid production levels $\left(60\right.$ g.L $\left.{ }^{-1}\right)$. Under these conditions, smaller beads resulted in higher acetification rates. Surface area of the beads had a significant impact on the acetification rates. Agitation promoted cell shear stress and insufficient acetification during fermentations. Gel entrapped cells using small beads under non-agitated fermentation conditions were effective for balsamic-styled vinegar production.
\end{abstract}

Keywords - Acetic acid bacteria, Balsamic-styled vinegar, Cell Immobilization, Agitated/static cultures, Non-Saccharomyces yeast.

\section{INTRODUCTION}

Traditional Balsamic Vinegar (TBV) is produced by fermenting cooked (concentrated) grape must of the grape varieties of Trebbiano or Lambrusco [1], [2] in barrels. The traditional method involves the use of an undefined/spontaneous inoculum by means of surface culture methods and the vinegar is matured for a minimum of 12 years after fermentation [1]-[4]. TBV can only be produced in Italy, in

U.F. Hutchinson, N.P. Jolly, H.W. du Plessis and C.K.L.N. Saulse are with the Post-Harvest and Agro-Processing Technologies, ARC Infruitec-Nietvoorbij (The Fruit, Vine and Wine Institute of the Agricultural Research Council), Private Bag X5026, Stellenbosch, 7599, South Africa.

S.K.O. Ntwampe, B.S. Chidi and M. Mewa-Ngongang are with the Bioresource Engineering Research Group (BioERG), Department of Biotechnology, Faculty of Applied Sciences, Cape Peninsula University of Technology, Keizersgracht and Tennant Street, Zonnebloem, P.O. Box 652, Cape Town, 8000, South Africa.. the provinces of Modena and Reggio Emilia. Therefore, any balsamic vinegar produced outside the demarcated areas cannot be called TBV. Thus, the term, balsamic-styled vinegar (BSV) was adopted for the vinegars in this investigation, where submerged methods such as agitation and cell immobilization by gel entrapment are investigated. Cell immobilization refers to the physical confinement or restriction of cells from being mobile or free-floating in the fermentation vessel [5]. Several vinegar studies have reported that cell immobilization reduces microbial sensitivity to harsh environmental conditions i.e. high acid, low $\mathrm{pH}$, high sugar, low water activity and osmotic stress in the fermentation vessel, thus improving acetification rates [6]-[9]. Cell immobilization is performed using various techniques, which include entrapment in a gel/within a porous matrix, flocculation (natural flocculation/aggregation, artificial flocculation/cross-linking), immobilization on a solid surface (adsorption on a surface, electrostatic binding on a surface or covalent binding on a surface), and mechanical containment behind a barrier (microencapsulation, interfacial microencapsulation, containment between microporous membranes) [10]. However, encapsulation within a gel and adsorption to a surface have been the most studied methods in vinegar fermentation systems [5]. Regardless of the techniques, cell immobilization has never been studied for any Balsamic vinegar fermentation. Thus, the aim of this study was to immobilize cells by gel entrapment and to evaluate the effect of bead size/surface area and agitation on acetification.

\section{MAterials AND MethodS}

\section{A. Preparation of Fermentation Medium}

Frozen Chenin blanc grape must $\left(25^{\circ} \mathrm{Brix}\right)$ was allowed to thaw at $28^{\circ} \mathrm{C}$. Subsequently, the grape must was boiled on a stove until the sugar concentration reached $30^{\circ} \mathrm{B}$. After cooling, a working volume of $350 \mathrm{~mL}$ was aliqouted into $500 \mathrm{~mL}$ Erlenmeyer flasks, covered with cotton wool stoppers and sterilised by autoclaving at $120^{\circ} \mathrm{C}$ for $20 \mathrm{~min}$.

\section{B. Pre-culture Preparation}

Cryopreserved non-Saccharomyces yeast $(\mathrm{n}=5)$ and acetic acid bacteria (AAB, n=5) (Table I \& II) cultures were obtained from 
the ARC Infruitec-Nietvoorbij culture collection. The inoculums were prepared by individually growing yeast and AAB in $100 \mathrm{~mL}$ YPD broth (Biolab, Merck, South Africa) and GM broth (glucose $0.8 \%$, mannitol $1.7 \%$, peptone $0.3 \%$, yeast extract $0.5 \%$ ) (Biolab, Merck, South Africa), respectively. Yeast and bacterial pre-cultures were incubated at $28^{\circ} \mathrm{C}$ for 48 and 72 hrs, respectively.

Table I: Non-Saccharomyces yeast used in the study.

\begin{tabular}{ll}
\hline \hline Identity & $\begin{array}{l}\text { ARC accession } \\
\text { numbers }\end{array}$ \\
\hline Candida pulcherrima & Y0839 \\
Candida zemplinina & Y1020 \\
Hanseniaspora guilliermondii & Y0558 \\
Kloeckera apiculata & $\mathrm{C} 48 \mathrm{~V} 19$ \\
Zygosaccharomyces bailii & $\mathrm{C} 45 \mathrm{~V} 69$ \\
\hline \hline
\end{tabular}

Table II: Acetic acid bacteria used in the study.

\begin{tabular}{lll}
\hline \hline Identity & $\begin{array}{l}\text { ARC } \\
\text { accession } \\
\text { numbers }\end{array}$ & NCBI accession \\
& numbers \\
\hline Acetobacter pasteurianus & $171 / 19$ & CP 021922.1 \\
Acetobacter malorum & $172 / 36$ & KU 686765.1 \\
Kozakia baliensis & $179 / 48$ & CP 014681.1 \\
Gluconobacter cerinus & $126 / 34$ & KX 578017.1 \\
Gluconobacter oxydans & $172 / 36$ & LN 884063.1 \\
\hline \hline
\end{tabular}

C. Calcium alginate infused YPD and GM preparation

A volume of $500 \mathrm{~mL}$ YPD and GM broths were prepared in a beaker. This was followed by preparing a $3 \%\left({ }^{w} / v\right)$ alginate solution by dissolving $15 \mathrm{~g}$ of sodium alginic salt (Biolab, Merck, South Africa) into the YPD and GM broth solutions, respectively. The alginate infused YPD and GM broth solutions were autoclaved at $120^{\circ} \mathrm{C}$ for $20 \mathrm{~min}$.

\section{Cell Immobilization: Small vs Large Beads}

Yeast and AAB cells were harvested by centrifugation of the liquid pre-cultures. The yeast and $\mathrm{AAB}$ cells were transferred to $250 \mathrm{~mL}$ YPD-alginate and GM-alginate solutions, respectively, and thoroughly mixed. Small $(4.5 \mathrm{~mm})$ beads (Fig. 1B) were prepared by extruding the alginate+broth solutions infused with cells through a $10 \mathrm{~mL}$ syringe. The beads were formed when a drop of the solution came into contact with a $0.9 \%\left({ }^{w} / v\right)$ sterile calcium chloride solution (Biolab, Merck, South Africa). The larger $(8.5 \mathrm{~mm})$ beads (Fig. 1A) were prepared by extruding the alginate solutions infused with cells through a large $10 \mathrm{~mL}$ plastic pipette tip, which was obtained by cutting off the edge of the tip. Both small and large beads were allowed to properly solidify for an hour in the calcium chloride solution [6], [11].
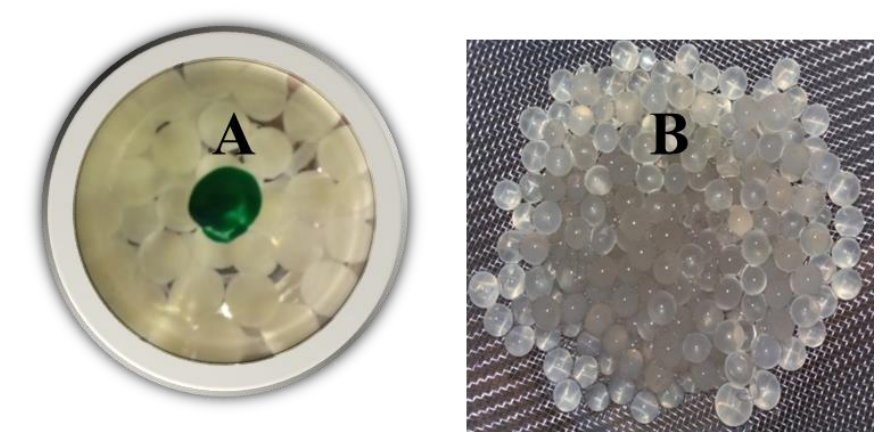

Fig. 1: (A) Large beads $(8.5 \mathrm{~mm})$ in calcium chloride solution, (B) Small beads $(4.5 \mathrm{~mm})$ on a sterile strainer.

\section{E. Inoculation}

An inoculum size of $2 \%(v / v)$ was used for both immobilized and free-floating cell fermentations. Immobilized cell fermentations were inoculated by dropping $20 \mathrm{~mL}$ of yeast and AAB beads, respectively into the fermentation containers. The YPD and GM alginate solutions contained $\sim 30 \%$ cells and therefore $20 \mathrm{~mL}$ of beads in $350 \mathrm{~mL}$ fermentation medium, making $2 \%$ inoculum (Fig. 2A \& B). The free-floating cell fermentations were inoculated with $7 \mathrm{~mL}(2 \% v / v)$ of the yeast and bacterial consortium (Fig. 2C).
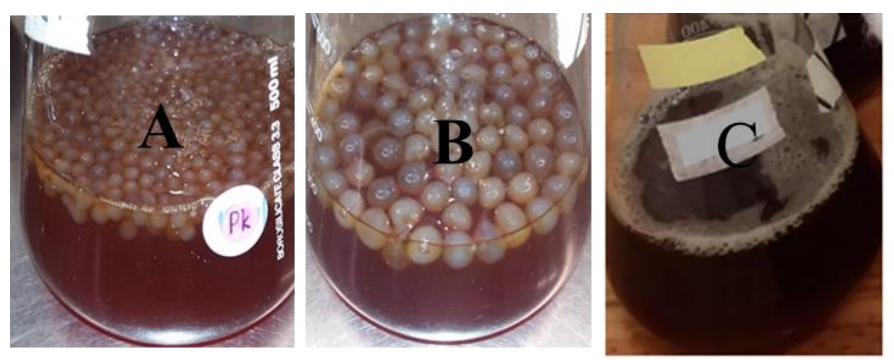

Fig. 2: Balsamic-styled vinegar fermentations using cooked Chenin blanc grape must. (A) Small and (B) large calcium alginate beads with entrapped yeast and $\mathrm{AAB}$ cells, $(\mathrm{C})$ free-floating cell fermentations.

\section{F. Batch Fermentation Setup and Sampling}

Fermentations (in triplicate) were incubated at $28^{\circ} \mathrm{C}$ for both agitated $(130 \mathrm{rpm})$ and static fermentation conditions. Samples were collected at an interval of 5 days for a period of 35 days. Samples were analysed for changes in sugar concentration ( ${ }^{\circ}$ Brix), total acid $\left(\mathrm{g} . \mathrm{L}^{-1}\right)$, alcohol $(\% \mathrm{v} / \mathrm{v})$ and $\mathrm{pH}$ using a density meter (Density meter DMA 35, Anton Paar, Austria), autotitrator (Hanna instruments minititrator HI 84502, South Africa), Alcolyzer Wine M (Anton Paar, Austria) and pH meter (Metrohm pH meter 632, Switzerland), respectively. Sugar and alcohol measurements were converted to g. $\mathrm{L}^{-1}$ for consistency.

\section{RESULTS AND DISCUSSION}

\section{A. Still vs Agitated Fermentation Kinetics}

A Traditional Balsamic Vinegar (TBV) fermentation is conducted under non-agitated conditions and not submerged in contrast to most industrial vinegars. Submerged methods include the use of technologically advanced systems making use of spargers, stirrers, coolers, antifoams, stainless steel fermentors, including automated control systems [12]. Therefore, the present study introduced submerged techniques 
in Balsamic-styled vinegar (BSV) production such as agitation and cell immobilization. Sugar consumption followed a similar trend for both small $(4.5 \mathrm{~mm})$ and large $(8.5 \mathrm{~mm})$ sized bead fermentations (Fig. 3A, D). The consumed sugar was calculated at the initial stages of the fermentation (day 0 to 3 ). It ranged between 161 to 176 g. $\mathrm{L}^{-1}$ for all treatments under agitated conditions, while the sugar consumed for all non-agitated fermentations ranged between 31 to 54 g.L $\mathrm{L}^{-1}$ (Fig. 3A, D). This indicates that the activity of the yeast consortium used was enhanced by agitation. Alcohol is an intermediary product/substrate in this context and the alcohol kinetics are difficult to explain, due to formation and consumption occurring simultaneously. Fig. 3B \& E shows that alcohol production was higher under agitated conditions compared to still conditions. This phenomenon was also supported by the sugar consumption kinetics (Fig. 3A), which is directly proportional to alcohol formation. Alcohol production during the initial stages (day 0 to 3 ), for agitated conditions was between 88 to $112 \mathrm{~g} . \mathrm{L}^{-1}$, while the alcohol produced for still fermentations was between 7.3 to 7.6 g. $\mathrm{L}^{-1}$ for all treatments.

....... Agitated small beads

$\longrightarrow$ Agitated large beads
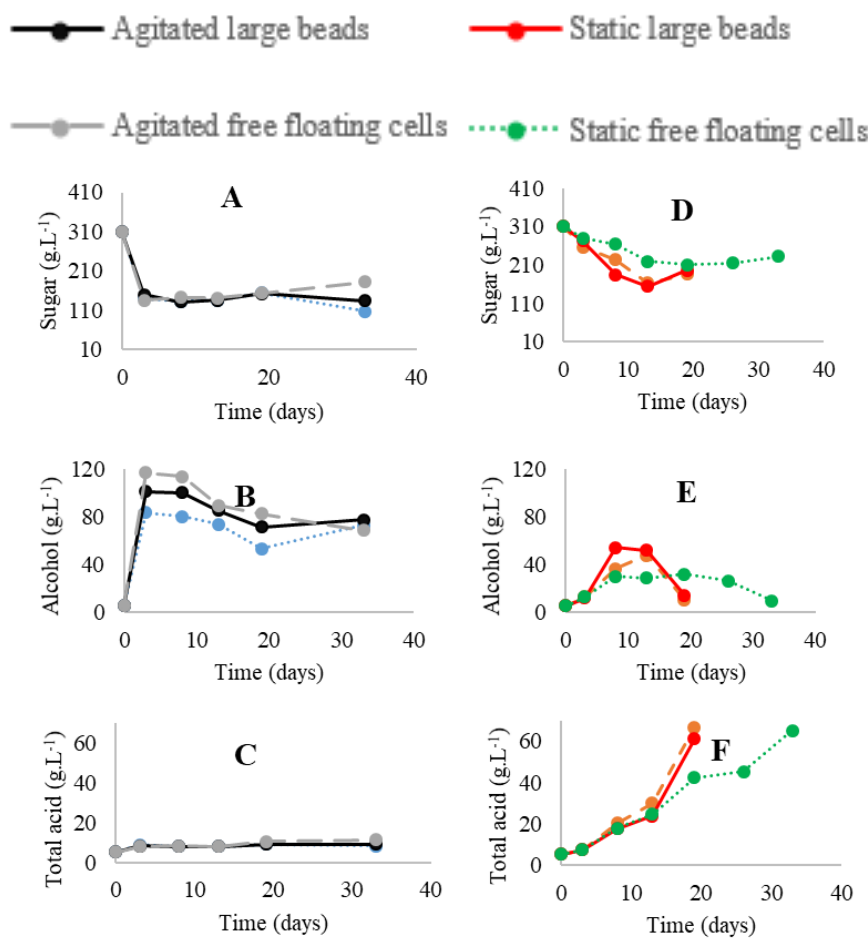

Fig. 3: Sugar consumption, alcohol and total acid production during the BSV fermentation process. Values are the means of three fermentations.

The acetification rate is the key step in BSV fermentation, as the strength of vinegar is gauged by assessing the final acetic acid concentration. In Balsamic vinegar, only $6 \%\left(60\right.$ g.L $\left.\mathrm{L}^{-1}\right)$ of acetic acid is required in the final product. Based on the acetification rates observed (Fig. 3C \& F), it appears that agitation does not favour acetification but rather promotes alcoholic fermentation. The results showed that agitation negatively affected the acetification process (Fig. 3C) and it is possible that the high agitation speed $(135 \mathrm{rpm})$ could have contributed to the reduced acetification profiles. Overall, acetification rates for both agitated (Fig. 3C) and still fermentations (Fig. 3F) displayed a rather constant and/or exponential acid production pattern throughout the fermentation. The acetification rates for agitated fermentations ranged between 0.1 to $0.2 \mathrm{~g} . \mathrm{L}^{-1}$.day ${ }^{-1}$, while the rates were 0.6 to 4.0 g. $\mathrm{L}^{-1}$.day ${ }^{-1}$ for still fermentations. Acetification was negatively affected by agitation (Fig. 3C), possibly due to shear stress and therefore requiring still/static conditions for optimum activity. Another possibility is that the high rate of alcohol production might have affected the survival/activity of $\mathrm{AAB}$, as they may have been unable to tolerate high alcohol concentrations. However, [13] reported that AAB are viable at an ethanol concentration of 10 and $14 \%(v / v)$. [14] found high strain variability among $\mathrm{AAB}$ strains with regard to ethanol tolerance and some AAB strains grew on a $5 \%(v / v)$ ethanol medium, while others grew on $10 \%(v / v)$. Agitation may not have been appropriate, using the gel-entrapment immobilization technique, as it causes damage to the beads and perhaps resulting in cell leakage, although cell leakage can also occur in non-agitated fermentations [15]. Photographs of the bead surface also support this hypothesis (Fig. 4). This damage (Fig. $4 \mathrm{~A}, \mathrm{C})$ prevented the re-usage of gel beads for subsequent fermentations. Non-agitated beads (Fig. 4B) appeared smoother with microscopically visible porosity (Fig. 4D), than those that were agitated (Fig. 4A, C).
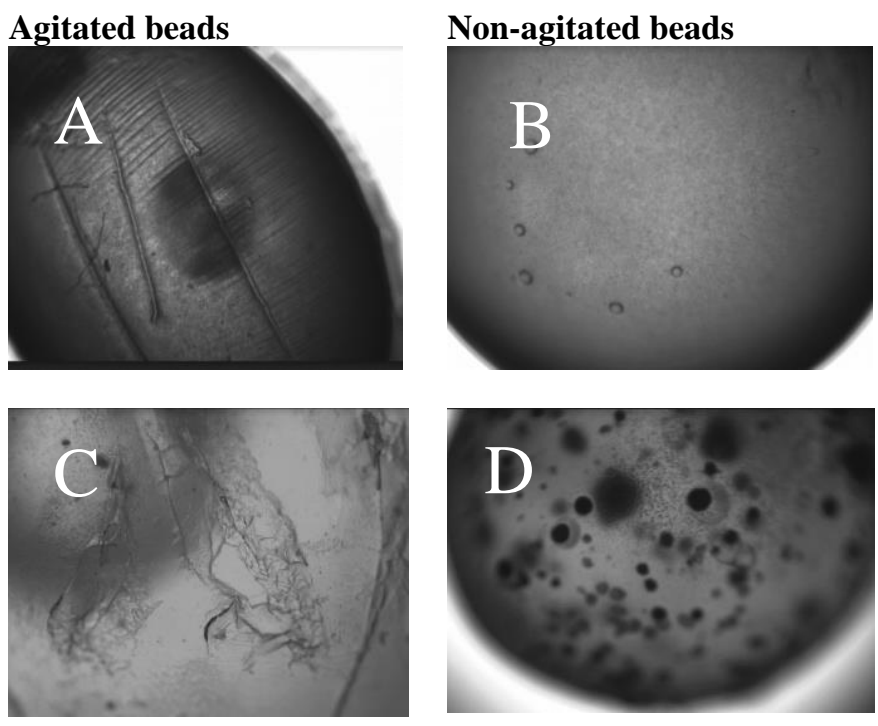

Fig. 4: External surface photographs of agitated and non-agitated Ca-alginate beads after fermentation. (A) Agitated bead at $100 \mathrm{x}$ magnification (B), non-agitated bead at 100x magnification, (C), agitated bead at 400x magnification (D), non-agitated bead at 400x magnification.

\section{B. Immobilized vs Free Floating Cell Fermentation Kinetics}

Cell immobilization by gel entrapment for BSV fermentations was investigated simultaneously with free-floating cell fermentations. Based on the results of fermentation kinetics, cell immobilization improved acetification rates under still conditions (Fig. 3F). All the fermentation kinetics were 
negatively affected by agitation (Fig. 3C) and are therefore not discussed in this section. Sugar consumption (Fig. 3D) followed a similar trend for both small $(4.5 \mathrm{~mm})$ and large $(8.5 \mathrm{~mm})$ sized bead fermentations, with less sugar being consumed during free-floating cell fermentations. Sugar consumption (Fig. 3D) was directly proportional to the alcohol produced (Fig. 3E). Improved total acid formation was achieved using immobilized cell fermentations compared to free-floating cells (Fig. 3F) while small beads were more efficient $\left(4.0\right.$ g. $\mathrm{L}^{-1}$.day $\left.{ }^{-1}\right)$ than large sized beads (3.0 g. $\mathrm{L}^{-1}$.day $\left.{ }^{-1}\right)$ and free-floating cells $(0.6$ g. $\mathrm{L}^{-1} \cdot$ day $\left.^{-1}\right)$. Furthermore, 60 g. $\mathrm{L}^{-1}$ of acetic acid was achieved after 16, 19 and 31 days for small sized, large sized beads and free-floating fermentations, respectively. [6] investigated adsorption on corncobs, bagasse and wood shavings and cell entrapment in $4 \%(\mathrm{w} / \mathrm{v})$ sodium alginate for sugar cane vinegar and found that adsorbed cells resulted in relatively higher acetification rates $\left(0.09-0.10 \mathrm{~g} . \mathrm{L}^{-1} \cdot \mathrm{h}^{-1}\right)$ compared to entrapped cells $\left(0.07 \mathrm{~g} . \mathrm{L}^{-1} \cdot \mathrm{h}^{-1}\right)$ and free-floating cells $\left(0.06 \mathrm{~g} . \mathrm{L}^{-1} \cdot \mathrm{h}^{-1}\right)$. These authors suggested that lower acetification rates by the entrapped cells may be caused by a low surface area, which leads to inadequate substrate and dissolved oxygen transfer rates.

\section{CONCLUSION}

Based on the results obtained, agitation of BSV fermentations is disadvantageous for the process system and optimisation of the agitation settings is necessary. Non-agitated (static) fermentations were effective, with entrapped cells resulting in higher acetification rates. The surface area of the beads also affects the acetification rates. Therefore, immobilized cells using small beads without agitation could be recommended for BSV production. More research work on the effect of air and oxygen transfer rate during BSV fermentations is recommended.

\section{ACKNOWLEDGMENT}

The Agricultural Research Council (ARC), colleagues, ARC work integrated learning students are acknowledged for the infrastructural resources, financial support and technical assistance.

\section{REFERENCES}

[1] L. Solieri, S. Landi, L. De Vero, and P. Giudici, "Molecular assessment of indigenous yeast population from traditional balsamic vinegar," Journal of Applied Microbiology, vol. 101, pp. 63-71, May. 2006.

[2] P. Giudici, and G. Rinaldi, "A theoretical model to predict the age of traditional balsamic vinegar," Journal of Food Engineering, vol. 82, pp. 121-127, September. 2007.

[3] L. Solieri, and P. Giudici, "Yeasts associated to traditional balsamic vinegar: ecological and technological features," International Journal of Food Microbiology, vol. 125, pp. 36-45, June. 2008.

[4] F. Chinnici, E. Durán Guerrero, and C. Riponi, "Discrimination of some European vinegars with protected denomination of origin as a function of their amino acid and biogenic amine content," Journal of the Science of Food and Agriculture, vol. 96, pp. 3762-3771, December. 2016.

[5] I. De Ory, L.E. Romero, and D. Cantero, "Optimization of immobilization conditions for vinegar production Siran, wood chips and polyurethane foam as carriers for Acetobacter aceti," Process Biochemistry, vol. 39, pp. 547-555, January. 2004.
[6] G.S. Kocher, K.L. Kalra, and R.P. Phutela, "Comparative production of sugarcane vinegar by different immobilization techniques," Journal of the Institute of Brewing, vol. 112, pp. 264-266, October. 2006.

[7] W. Krusong, and A. Vichitraka, "An air-lift acetifier with mash recycling system for corn vinegar production by adsorbed cells of Acetobacter aceti WK on surface of loofa sponge," In 2nd International conference on biotechnology and food science IPCBEE, pp. 86-90, Vol. 7, Singapore: IACSIT Press, 2011.

[8] G. Kumar, A. Mudhoo, P. Sivagurunathan, D. Nagarajan, A. Ghimire, C.H. Lay, C.Y. Lin, D.J. Lee, and J.S. Chang, "Recent insights into the cell immobilization technology applied for dark fermentative hydrogen production," Bioresource Technology, vol. 219, pp. 725-737, November. 2016.

[9] J. Żur, D. Wojcieszyńska, and U. Guzik, "Metabolic Responses of Bacterial Cells to Immobilization," Molecules, vol. 21, pp. 958, July. 2016.

[10] Y. Kourkoutas, A. Bekatorou, I.M. Banat, R. Marchant, and A.A. Koutinas, "Immobilization technologies and support materials suitable in alcohol beverages production: a review," Food Microbiology, vol. 21, pp. 377-397, August. 2004.

[11] N. Kaushal, and R.P. Phutela, "Vinegar Production from Barley Malt using Immobilized Gluconobacter oxydans, "International Journal of Pure and Applied Bioscience, vol. 5, pp.264-271, October. 2017.

[12] R. Fernández-Pérez, C. Torres, S. Sanz, and F. Ruiz-Larrea, "Strain typing of acetic acid bacteria responsible for vinegar production by the submerged elaboration method," Food Microbiology, vol. 27, pp. 973-978, December. 2010.

[13] W.J. Du Toit, and I.S. Pretorius, "The occurrence, control and esoteric effect of acetic acid bacteria in winemaking," Annals of Microbiology, Vol 52, pp.155-179, nd. 2002.

[14] M. Gullo, and P. Giudici, "Acetic acid bacteria in traditional balsamic vinegar: phenotypic traits relevant for starter cultures selection," International Journal of Food Microbiology, vol. 125, pp. 46-53, June. 2008.

[15] J.H. Tsen, Y.P. Lin, and V.A.E. King, "Fermentation of banana media by using $\quad \kappa$-carrageenan immobilized Lactobacillus acidophilus," International Journal of Food Microbiology, vol. 91, pp. 215-220, March. 2004.

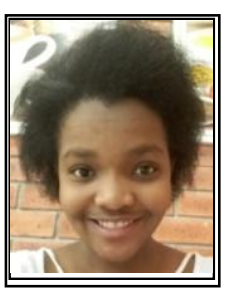

Ucrecia Faith Hutchinson was born in Mpumalanga, South Africa (23 November 1991). After obtaining a bachelors certificate in Mahhushe Agricultural High school (2009) on science subjects (biology, physics, mathematics, chemistry and agricultural sciences), she pursued a National Diploma (ND) in Biotechnology and completed in 2013. She then continued to pursue a Bachelor of Technology (B-tech) in Biomedical technology (2014) followed by a Master's degree (MEng) in Chemical Engineering (Cum Laude) (2016). All the aforementioned degrees were obtained at the Cape Peninsula University of Technology, Cape town, South Africa. Due to her interest in research, she is currently pursuing her Doctor of Philosophy $(\mathrm{PhD})$ in Chemical Engineering at the Cape Peninsula University of Technology, Cape Town, South Africa under the supervision of Prof Seteno Karabo Ntwampe and Doctor Neil Jolly (Agricultural Research Council).

Her work experience includes "work integrated learning" at the Agricultural Research Council Infruitec-Nietvoorbij (2013) which was a prerequisite for her national diploma. She has continued with ARC from 2013 up to date where she simultaneously receives research work experience while pursuing her postgraduate studies. In 2017 she was awarded a price for the $3^{\text {rd }}$ best $\mathrm{PhD}$ presentation at the ARC Professional Development Program (PDP) annual postgraduate conference. She has currently sent two manuscripts for publication titled "An assessment of vinegar engineering: A bioprocess perspective" and "Product and microbial population kinetics during Balsamic-styled vinegar production". 